\title{
Role of Thinking in Learning
}

\section{- Purna Bahadur Kadel}

\begin{abstract}
Thinking is essential for learning. Thinking is inextricably intertwined with learning. Teaching thinking refers to teaching critical and creative thinking skills and problem solving tasks. Critical thinking incorporates reasoning, logical judgment, metacognition, reflection, and mental process in course of learning. It involves evaluation, analyzing, and interpreting the problems to find out the solution. Creative thinking can be enhanced through multiple intelligence, affective factors, and innovative curriculum. Metacognition and thinking are must to solve any task in learning language.
\end{abstract}

Key words: Thinking, metacognition, intelligence, innovation, affective factors.

\section{Introduction}

Thinking refers to all the mental activities like daydream, wishes, fantasies, images of having new ideas, philosophical theorizing, political argument, making decision, reading, writing, and planning. Thinking can be categorized as critical thinking, creative thinking, reflective thinking, higher level thinking, logical and reasoning thinking skills, and problem solving. Teaching thinking means teaching critical thinking and creative thinking skills to enhance teaching and learning activities. The knowledge of thinking can be achieved from philosophy and psychology.

Waters (2006) argues that thinking is very essential in language learning. Learning occurs if the mind of the learners can connect the current level of knowledge with the prior knowledge during learning. English language teaching
(ELT) activity should promote thinking process of the learners for meaningful learning. Broadly speaking, learning is impossible without thinking process. The rote-learning cannot promote thinking since there is no cognitive process in rote- learning. So, learning is inextricably intertwined with thinking. Waters (2006, p. 320) describes Sander's (1996) adaptation of Bloom's framework which becomes a milestone for developing thinking and learning.

- Memory: the recall or recognition of information.

- Translation: changing information into a different symbolic form or language.

- Interpretation: discovery of relationship among facts, generalizations, definition, values, and skill.

- Application: solving a lifelike problem that requires the identification of the 
issue and the selection and use of appropriate generalizations and skills.

- Analysis: solving the problem in the light of conscious knowledge of the parts and forms of thinking.

- Synthesis: solving a problem that requires original, creative thinking.

- Evaluation: making a judgment of good or bad, right or wrong, according to standards designated by student.

In Halpern's words (2007) critical thinking is the use of those cognitive skills or strategies that increase the probability of a desirable outcome. It is used to describe thinking that is purposeful, reasoned and goal-directed - the kind of thinking involved in solving problems, formulating inferences, calculating likelihood, and making decisions, when the thinker is using skills that are thoughtful and effective for the particular context and type of thinking task.

Critical thinking is more than sheer thinking. It uses skills, abilities, and strategies to encounter with any problem solving tasks to make a desirable outcome. Critical thinking subsumes reasoning, logical judgment, metacognition, reflection, and mental processes in course of learning to think for solving any problems.

By and large, there are two taxonomies of critical thinking skill such as higher order thinking skills and lower order thinking skills. Higher order thinking skill is meaningful learning which requires judgment, analysis, and synthesis. Moreover, higher order thinking skills are reflective, sensitive to the context, and selfmonitored since higher order thinking is judgmental task which has more credibility and multidimensional quality. There can have plans approach with grading and sequencing of problem solving tasks in higher order thinking skills to recognize the problems and in turn to solve them thoroughly.

Lower order thinking skill is memorizing, rotelearning, and parrot learning, which is unreflective and inapplicable. It does not help the learners to develop critical thinking and creative thinking skills. On the contrary, meaningful learning helps the learners to develop critical and creative thinking skills to solve any problems in their practical life.

According to Halpern (2007) critical thinking is similar to intelligence in many ways. The critical thinking skill can be developed through scientific pedagogy and inductive instruction. As such, it can be transferable from person to person as ordinary skills. One of the components of critical thinking is conscious reflection on the process of thinking and the evaluation of one's thinking process. Metacognition is related to personal knowledge and relation to understanding of one's own cognitive process.

According to Gilhooly (1998) thinking and memory are inextricably intertwined with each other which play a crucial role in learning all types of skills for language learning and intellectual development. Thinking is absolutely cognitive activities which involves in solving problem, decision making, planning, and comprehending complex materials. Memory comprises of working memory and long term memory which involves encoding, decoding, retention, and retrieval of information. Thinking is inextricably intertwined with long term and short term memory. Particularly, long-term memory is essential for developing critical and creative thinking skills in enhancing second language learning. Ruggiero (1988) states that 
teaching thinking skill means to make the learner creative thinker, critical thinkers, and problem solver in course of developing higher order thinking skill.

In fact, thinking is a very powerful weapon to develop the abilities of planning, decision making, and problem solving, independently. Thinking refers to hypothesizing, interpreting, seeking alternative views, raising questions, evaluating, discovering, and finding the solution of the problems. Thus, students' cannot develop their language proficiency without thinking skills. There are mainly three types of thinking activities such as making decision, analyzing, and problems solving.

Ruggiero (1988, p. 28) argues that "thinking is any mental activity that helps formulate or solve a problem, make a decision, or fulfill a desire to understand; it is a searching for answers or reaching for meaning" In fact, thinking comprises creative and critical thinking. Creative thinking helps the learner to solve the problems by discovering some unique ideas, and techniques. However, critical thinking involves evaluating, analyzing, and interpreting the problems to find out the solution. Critical thinking is responsible for the monitoring and appraising of any newly created work. It is a means by which assertions and arguments are evaluated in light of available evidence. There are some strategies to enhance creative thinking, such as forcing uncommon responses, using free association, using analogy, looking for unusual combination, visualizing the solutions, constructing the pros and cons of arguments, and constructing relevant scenarios.

According to Dewey (1933) belief, attitude, and responsibility are inevitable to generate new thinking. There should be harmonious relation among belief, attitude, and responsibility with thinking. The ability to think is very important in the life of human beings which distinguishes them from animals. Thinking enables us to solve any critical problems and to achieve future plans.

\section{Critical thinking skills}

Critical thinking is an ability which is essential to have successful performance in learning and in solving problems. The learners can understand the realities of the world through the view point of critical thinking. Critical thinking is a cognitive process which is required to develop cognitive thinking activities for solving problems regarding learning and other issues. Evaluation, synthesis, analysis, application, interpretation, translation, and memory are critical thinking skills and cognitive processes which can be applied to achieve all kind of learning including language learning. Critical thinking abilities help in developing performance of the learners not only on listening and speaking, reading, and writing but also in developing mata-cognitive, cognitive, and affective strategies. Critical thinking has been used as a tool in teaching and learning for second language.

There are some reasons of teaching and learning critical thinking in ESL, such as a social practice, dominant current concept of critical thinking, opposite concept of thought and education. Critical thinking is regarded as metacognitive strategy. Higher order thinking skills refers to problem solving tools in learning critically and creatively. Atkinson (1997) argues that critical thinking was confined only in L1 setting as process writing schema theory and collaborative learning before 1990s. However, it started to dominate in teaching and learning 
of second language effectively since 1990s onwards.

Critical thinking is regarded as social practice for socializing the children through cognitive development. People apply critical thinking as a means for literacy socialization in the society. Furthermore, it is used to develop for analytical writing of non-native learners. In fact, critical thinking helps to develop metacognitive strategy in which the learners are made think about their learning themselves. Thus, they become selfregulated, self-monitored, and self-motivated through the critical thinking skills. People use critical thinking for developing intellectual skill. Since 1990s, critical thinking was used to teach and learn second language in developing cognitive and metacognitive strategies of second language learners effectively. In Japanese culture, critical thinking is focused on individual socialization since individuals are the fundamental unit of social foundation. It is believed that the individual should develop concepts of critical thinking for the socialization and solving problems as a means to learn language.

Foster and Pikkert (1996) argue that critical thinking is a skill which should be included in every subject since it is an evergreen and everlasting skill to solve problems. In fact, it is an inevitable to judge, analyze, reflect, and to employ for the problem-solving activities in learning. They, furthermore, argue that critical thinking is a higher order thinking skill which is required to evaluate, reflect, judge, criticize, and analyze in course of learning and problem solving activities. Thinking has two components, such as creative thinking and critical thinking. Both creative thinking and critical thinking are higher order thinking skills which help the learners for cognitive development. Creative thinking helps the learners to imagine and to origin uncommon unique ideas. It helps to develop logical reasoning to solve any problems or tasks. However, critical thinking helps the learner to develop the evaluative, judgmental, monitoring, and appraisal thinking capacity to solve the problems.

According to Stroupe (2006) critical thinking is very significant to include in educational curricula for the multidimensional development of second language learners. It is very significant for the improvement of analysis, synthesis, and evaluation repertoire of second language learners for developing language learning and teaching. The incorporating of critical thinking in educational curricula helps to embark interactive and cooperative teaching and learning by superseding traditional curricula in language learning. Critical and creative thinking skills are subsets of cognitive skill which guides the learners to be rationale, creative, self-regulated, self-directed, and self-appraisal. The main objective of introducing critical thinking curricula is to make the learners self-regulated, self-autonomous, and self-assessing and to make proficient learners in target language. Critical thinking curricula make the learners interpretive, evaluative, creative, logical, rational, and thoughtful.

\section{Creative thinking skills}

A creative thinking skill is a building block to develop the cognition of the children. The learners can solve any problems intuitively and analytically through the application of creative thinking skills. The affective and cognitive factors are vital to develop creative thinking skills of the children. They can develop the creativity through self-confidence, self-efficacy, 
and motivation. The self-efficacy is very inevitable for the learner to be self-regulated which enhances cognitive development. When learners become self-regulated, they will develop the creative thinking skills. The self-confidence and self-capacity can help to accomplish any complex tasks on their own endeavors through creative thinking skill. Motivation, metacognition, and cognitive strategies are fundamental and essential facets to develop the creative thinking skills.

According to Nagaraju (2008) if the individual learners are instructed and behaved on the basis of their individual differences (IDs), their creativity will be developed. Intelligences play a vital role to strengthen creative thinking skills of the learners. The multi-intelligences can be fostered though academic instruction and special training. Children can achieve mastery in more than two intelligences which depend on the individual differences. Multiple intelligences are not inborn and innate endowment of human beings. However, they can be acquired through academic and non-formal instruction. So children's creative thinking skill can be enhanced through multiple intelligences.

In order to develop the creative thinking skills of the learners, there should be innovation and improvement in the syllabus, teaching materials, teaching methodology, efficiency of the instructors which help to develop the creativity of learners effectively. The learner-centered syllabus should be with well-graded and sequenced tasks in terms of task complexity,

Well-equipped teaching and learning materials can help to promote creative thinking skills of the learners. However, teacher centered teaching materials and instructions always play the negative effect in developing the creativity of the learners. Furthermore, self-esteem, anxiety, learning style and strategy, and affective factors influence the creativity of the learners. However, the self- esteem, good learning styles, and anxiety promote the creativity of learners.

According to Rao (1990, p. 269) the creativity in the learners can be developed as follows

- Encourage self-expression in spontaneous and planned activity.

- Provide incentives and reinforcements for practice.

- Value creative thinking.

- Make children more sensitive to environmental stimuli.

- Encourage manipulation of objects and ideas.

- Develop the tolerance of new ideas.

- Develop a creative classroom atmospherea free relaxed unhurried one.

- Encourage the students to build their ideas in concrete forms whenever possible.

- Teach skills for avoiding peer's sanctions.

- Give information about the creative process.

- Develop the metacognitive strategies.

- Encourage the acquisition of knowledge in variety of fields.

- Develop the constructive criticism

\section{Problem solving tasks}

Problems in second language learning are cognitively demanding which cannot be solved unless learners involve in cognitive processes to solve them. The learners should develop 
cognitive and metacognitive strategies to get the goal of the learning. In second and foreign language learning, problem is created as the learners are unable to find appropriate strategy to solve the problems. The learners should develop critical thinking skills, such as creative thinking, reasoning, and logical skill, and problem solving skills to solve all kinds of language learning problems. Apart from critical thinking skills, learners can develop metacognitive skills, such as self-monitoring, self-regulated learning, self-judgment, problem based learning to solve the tasks. The taskbased teaching and learning strategy can be very significant to solve the problems to some extent.

According to Nunan (2006) task is a piece of classroom work that involves learners in comprehending, manipulating, producing or interacting in the target language. The learners intend to convey meaning through mobilizing their grammatical knowledge. They focus on meaning rather than forms. In task-based learning, task involves communicative language use and deploying of grammatical knowledge to express meaning. Meaning and form are very interrelated in task-based language teaching and learning. Nunan has differentiated between real world or target tasks and pedagogical task. The target task is used in real world beyond the classroom whereas classroom tasks are simulated in classroom activities.

Ellis (2006) has introduced three principle phases of tasks, such as pre-task, during-task, and post-task. In pre-task phase, the learners involve framing the activity and planning time. During- task phase, the task itself provides various instruction, and active participation of learners to carry out the task. In post-task phase, the learners involve in repeating the task, reporting, and critiquing.

In task-based language learning and teaching, the notion of task as a central unit of the planning and teaching. Ellis (2003) points out about taskbased language teaching as follows:

- Focus on process rather than product

- Focus on meaning rather than form

- Emphasize on interaction, communication, and meaning.

\section{Conclusion}

Thinking is inevitable in language learning. There is symbiotic relationship between thinking and language learning. Thinking comprises critical and creative thinking skills which are also called higher order thinking skills. The meaningful learning is occurred only through higher order thinking skills. Rote learning and memorization are due to the absence of critical and creative thinking skills. Thinking is considerably cognitive activities which can be enhanced through problem solving tasks, planning tasks, decision making tasks etc. Thinking without language learning process is impossible and vice-versa. Cognitive development of learning takes place in social context and learning is arisen by the cognitive behaviour of the learners.
About the author
Dr. Kadel is Lecture of English Education of TU at Surkhet Campus (Education). He has earned Ph.D in ELT domain from The English and Foreign Languages University, Hyderabad. He has presented a number of articles at home and abroad. He has also authored a number of articles in national and international journals. His specialization areas are academic writing and task-based language teaching. 


\section{References}

Atkinson, D. (1997). A critical approach to critical thinking in TESOL.TESOL Quarterly, 31(1), 71-94.

Dewey, J. (1933). How we think. Boston: D.C. Health and Company.

Ellis, R. (2003). Task-based language learning and teaching. Oxford: Oxford University Press.

Ellis, R. (2006). The methodology of task-based teaching. Asian EFL Journal, 8 (3), 19-45.

Foster, L., \& Pikkert, J. J. J. (1996). Critical thinking skills among third year Indonesian English students. RELC, 27, (2), 56-64

Gilhooly, K. (1998). Working strategies and reasoning tasks. In Robert H., \& Kenneth J. Gilhooly (Eds.). Working memory and thinking. London: Psychology Press Ltd a member of the Taylor \& Francis group.

Halpern, D. F. (2007). The Nature and Nurture of Critical Thinking: In Robert J. Sternberg, Henry L. Roediger III, \& Diane F. Halpern (Eds.). Critical Thinking in Psychology (pp. 1-14). Cambridge: Cambridge University Press.

Nagaraju, M. T. V. (2008). Psychology of Learning and Instruction. Delhi: Manglam Publications.
Nunan, D. (2006). Task-based language teaching in the Asia context: Defining task, Asian EFL Journal, 8(3), 12-18.

Rao, S. N. (1990). Educational Psychology. New Delhi: Wiley Eastern Limited,

Roggiero, R. V. (1988). Teaching Thinking across the Curriculum. New York: Harper $\&$ Row, Publisher, Inc.

Sanders, E. R. (2005). Validating 'observations' in discourse studies: A methodological reason for attention to cognition. In Hedwig the Molder, \& Jonathan Potter (Eds.), Conversation and Cognition (pp. 57-78). Cambridge: Cambridge University Press.

Sanders, N. M. (1966). Classroom QuestionsWhat Kinds? New York: Harper and Row

Stroupe, R. R. (2006). Integrating Critical Thinking Throughout ESL curricula. TESL Reporter, 39 (2), 42-61

Vygotsky, L. S. (1978). Mind in society: The development of higher order psychological process (Eds.), Michael Cole, Versa john-Steiner, Sylvia Scribner \& Ellen Souberman. Cambridge: Harvard University Press.

Waters, A. (2006). Thinking and language learning. ELT Journal, 60 (4), 319-327 